\title{
HYDROMECHANISM AND DESALINATION OF COASTAL KARST AQUIFERS: THEORY AND CASES
}

\section{HIDROMEHANIZEM IN RAZSLANITEV OBALNIH KRAŠKIH VODONOSNIKOV: TEORIJA IN PRIMERI}

\author{
Marko BREZNIK ${ }^{1,2}$, \& Franci STEINMAN ${ }^{1,3}$
}

\begin{abstract}
UDC 556.114.5:627.8.034

Marko Breznik \& Franci Steinman: Hydromechanism and desalination of coastal karst aquifers: Theory and Cases

Brackish water of coastal karst aquifers is useless. Desalination methods are: interception method to capture fresh water in karst massif, isolation and rise-spring-level methods to prevent sea water inflow and reduced pumping of fresh water in dry periods. Four typical cases explain these methods.
\end{abstract}

Key words: coastal karst aquifers, desalination, methods, cases.
Izvleček

UDK 556.114.5:627.8.034

Marko Breznik \& Franci Steinman: Hidromehanizem in razslanitev obalnih kraških vodonosnikov: Teorija in primeri

Somornica obalnih kraških vodonosnikov je neuporabna. Načini razslanjevanja so: prestrezanje sladke vode $\mathrm{v}$ kraški gmoti, izolacija vodonosnika in dvig gladine izvira za preprečenje vtoka morske vode, ter zmanjšanje črpanja sladke vode $\mathrm{v}$ sušnih obdobjih. Te načine pojasnjujejo štirje tipični primeri.

Ključne besede: obalni kraški vodonosniki, razslanjevanje, načini, primeri.

\section{INTRODUCTION}

In the Ice ages were the differences between the lowest mean temperatures of the cold periods and the highest ones of the warm periods 5 degrees Celsius. These differences between the lowest ones of the Ice ages and the present highest ones are 7 degrees Celsius. During the last 30 years, 10 warmest were between 1990 and 2006. We are living probably in the warmest period during the last 150.000 years (Rošker 2007). The yearly air temperatures in Ljubljana have increased by 1,7 degrees Celsius in the last 50 years (Kajfež-Bogataj, 2006). Sixty years ago, we have to walk for $1 \mathrm{~km}$ over the Triglav mountain's glacier, after climbing over the Triglav's north wall, $800 \mathrm{~m}$ high. This glacier has nearly melted till the present.

Precipitations have decreased from 1100 to 1000 $\mathrm{mm}$ /year in the Trieste town during last 100 years. Italian scientists believe that the Azore islands' anticyclone with sunny weather has extended towards the Mediterranean. Precipitations in the Portorož town have decreased by $14 \%$, during the last 50 years (Kajfež-Bogataj 2006). An about $1000 \mathrm{~km}$ large belt of severe drought hazards event extends along the southern Spain, Italy, Greece, Turkey and northern Africa to Syria and Iraq.

Lučka Kajfež-Bogataj, Professor of the Ljubljana University and the Vice-chair of the Working Group II: Impacts, Adaptation and Vulnerability of the Intergovernmental Panel on Climate Change (IPCC), warns that the climate changes will continue and threaten the world population with shortages of water, energy and food. The adaptive measures have to be taken quickly. The proposed desalination of larger karstic coastal springs could provide fresh water for drinking and irrigation.

\footnotetext{
${ }^{1}$ Hydrotechnical Sec., Faculty of Civ. Eng. and Geod., University of Ljubljana, Hajdrihova 28, 1000 LJUBLJANA, Slovenija

${ }^{2}$ Vrtača 8, 1000 LJUBLJANA, Slovenija

${ }^{3}$ Franci.Steinman@fgg.uni-lj.si

Received/Prejeto: 16.7.2008
} 


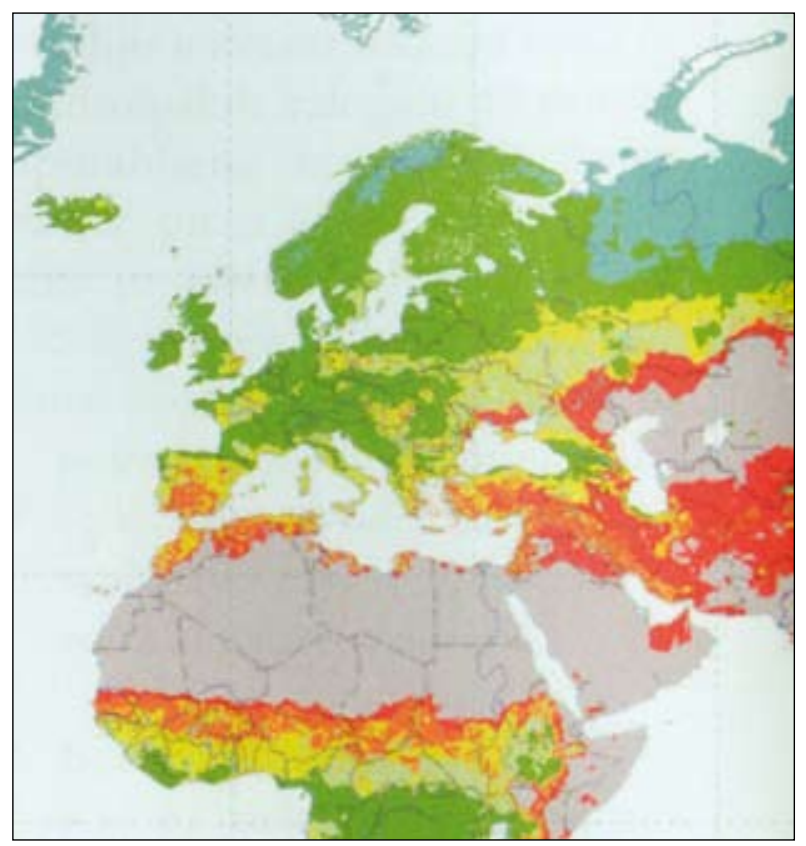

Fig. 1: Vulnerability of Mediterranean countries to severe droughts (USDA and Kajfež-Bogataj 2006).

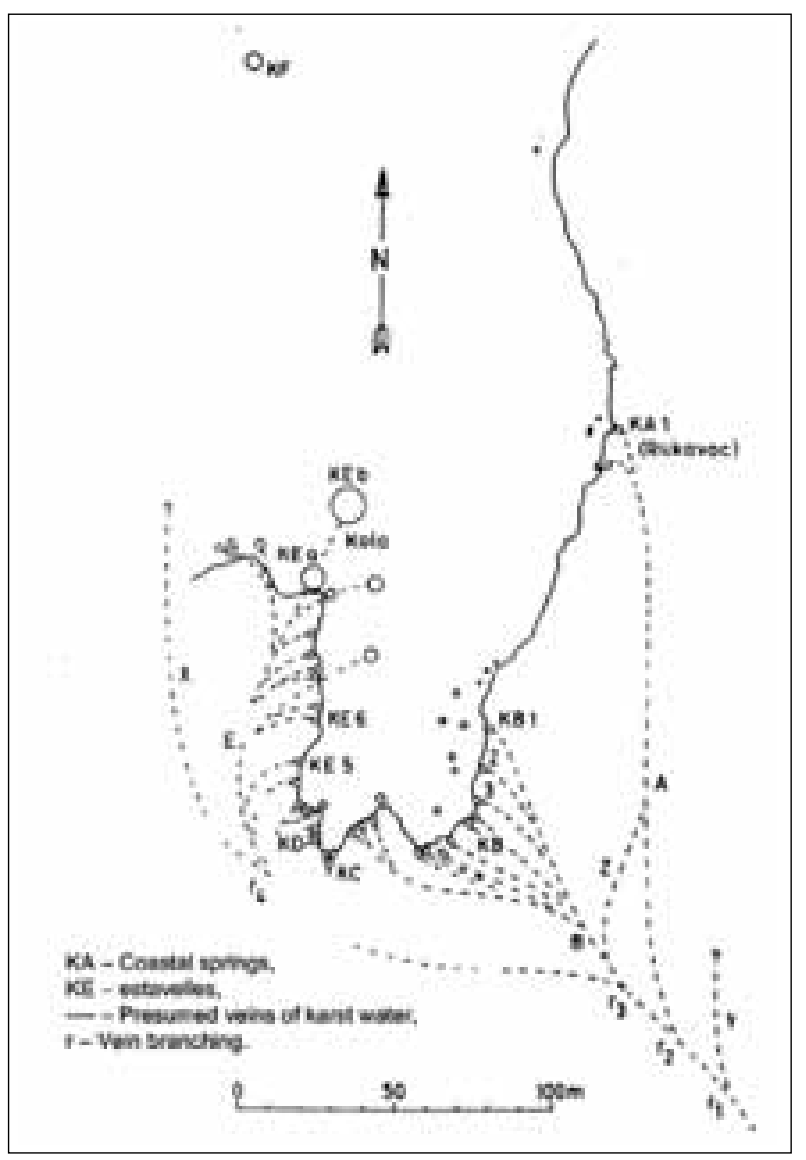

Fig. 2: Jurjevo bay in Northern Adriatic (Kǔšcer 1943).

\section{THEORY}

Brackish springs are regular phenomena of coastal karst aquifers. Their desalination is of great human and economic importance now, and will be greater in a drier Southern Europe due to intensive climatic changes in the future. Diffused types of the groundwater flow exist in the granular soil and in the intensely karstified carbonate rock (coastal aquifer of Israel). The outflow of either fresh or brackish water is regulated by the position of the interface or the zone of mixing and has been explained by Badon Ghyben in 1888. This paper does not discus such aquifers.

The Ghyben - Herzberg law (1901) explains the influence of different densities of fresh and sea water. The water pressure below a $41 \mathrm{~m}$ high column of fresh water is equal to that below a $40 \mathrm{~m}$ high column of sea water.

Karst groundwater flows along channels and along karstified tectonic zones, called also veins. This is the conduit type of the karst groundwater flow. Prof. Gjurašin of Zagreb observed a rarely visible inflow of sea water in the Gurdić spring near the Kotor town in the Southern Adriatic. He published his theory of 3 karst veins in 1943.

Students with I. Kuščer examined in Jurjevo bay 70 coastal and submarine springs and 30 estavelles in 1938-1940 and with a tracing test in 1947. During rainy periods all the springs and the estavelles deliver fresh water. In the spring time with the decreasing discharge, the outflow of estavelles stops and sea water intrudes and contaminates some springs by $700 \mathrm{mg} / \mathrm{l} \mathrm{Cl}$. The estavelles change from springs to ponors in 1 to 2 days. All springs have till $9000 \mathrm{mg} / \mathrm{l} \mathrm{Cl}$ in the autumn (Kuščer 1950).

Breznik examined the coastal springs and the estavelles in 40 karst places in the former Yugoslavia, Greece and Turkey since 1956. Fresh water from the karst massif is drained through the primary vein, which branches into the lower vein, connected with sea, and into the upper vein, leading to the spring. The present lower veins were formed in past geological periods by the fresh water flowing toward the sea, at a lower level and were primary veins in these periods. Sea water later drowned them, either due to the tectonic subsidence of the massifs in the Tertiary to Holocene periods, or due to melting of the Pleistocene ice. The levels of the Mediterranean Sea were for over 100 $\mathrm{m}$ higher in the Lower Tertiary and for $120 \mathrm{~m}$ lower in the Pleistocene periods than today (Bosi et al. 1996, Bonifay 1974). Karst water formed new channels to the actual sea surface, and these are the present upper veins and springs. 


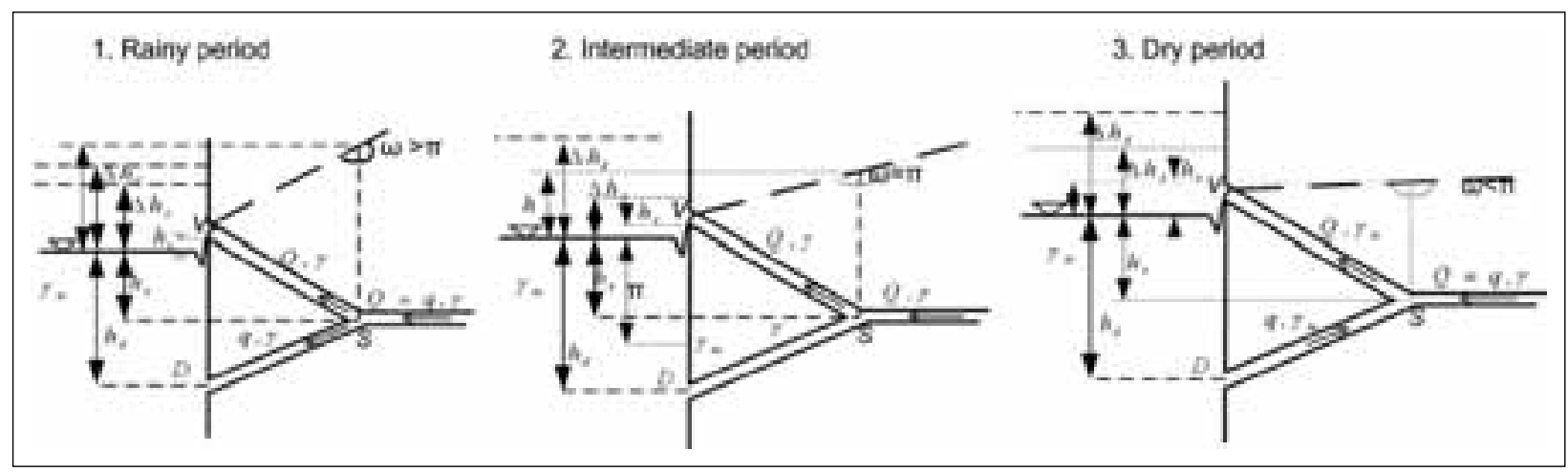

Fig. 3: Outflows of the Gurdić spring in the Southern Adriatic (Gjurašin 1943).

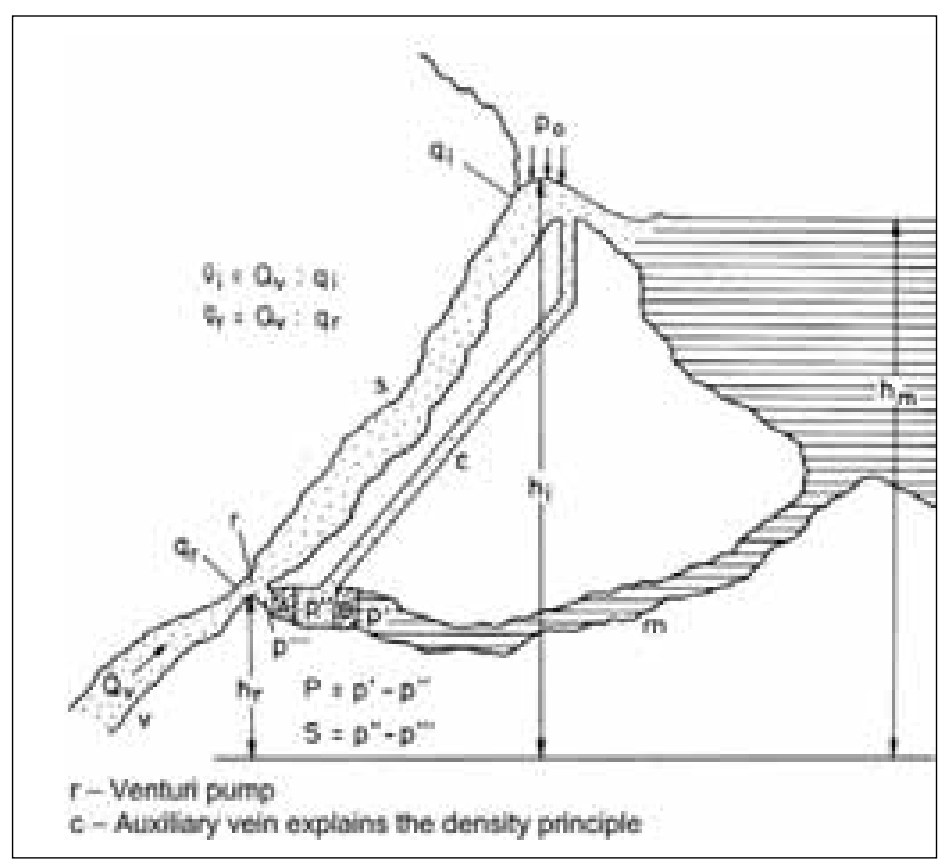

Fig. 4: Coastal spring of a conduit type (Kuščer 1950). Flow in a karst aquifer (Kuščer 1950).

Fig. 5: Scheme of veins in the conduit- type karst aquifer of a coastal spring (Breznik 1973).

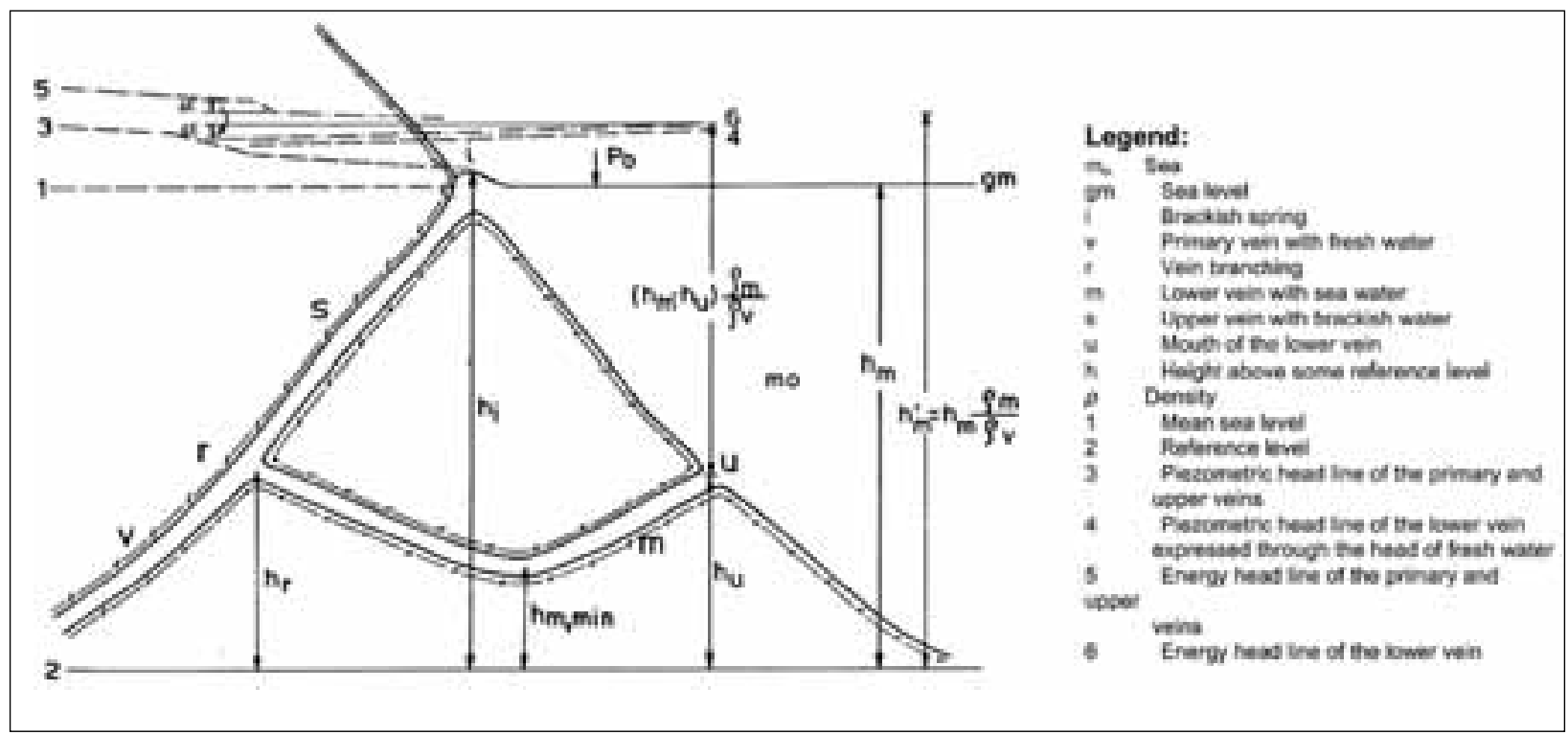




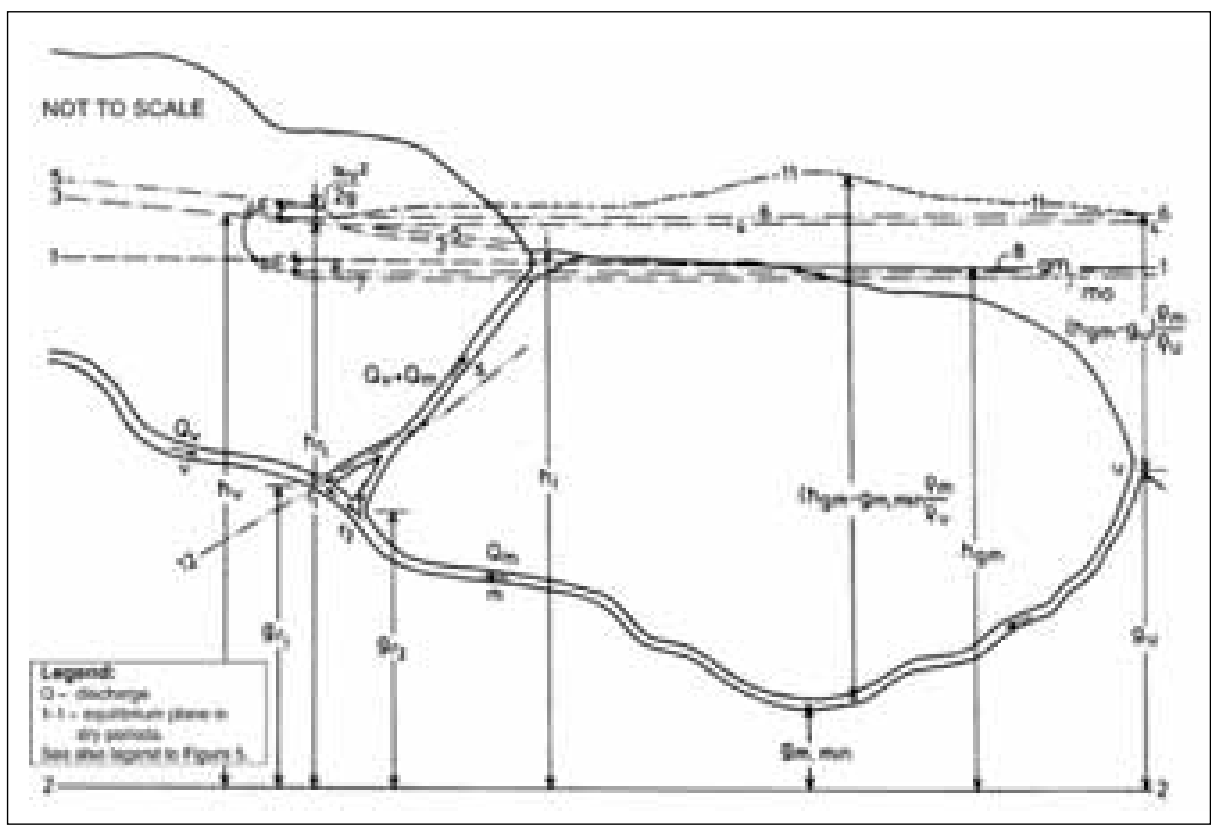

Fig. 6: Contamination with sea water of a coastal spring, with a very deep siphon like lower vein, during dry periods (Breznik 1990).

Sea water can penetrate into a vein-branching if the pressure in the lower vein exceeds that in the upper one. Processes follow equation, given by Breznik (1973):

$\left.h_{i}-h_{r}\right\rangle \frac{\rho_{m}}{\rho_{m}-\rho_{s}}\left(h_{i}-h_{m}\right)+\frac{\rho_{m} T_{m}+\rho_{s} T_{s}}{\rho_{m}-\rho_{s}}-\frac{v_{s}^{2} \rho_{s}-v_{m}^{2} \rho_{m}}{2 g\left(\rho_{m}-\rho_{s}\right)}$ where are:

$\rho$ - density, $g$ - gravity acceleration, $\mathrm{h}$ - height above refer. level, $\mathrm{Q}$ - discharge, $\mathrm{T}$ - head loss in a vein, $\mathrm{v}$ - velocity, $\mathrm{v}^{2} / 2 \mathrm{~g}$ - velocity head, $\mathrm{m}$ - sea water, $\mathrm{s}$ - fresh water.

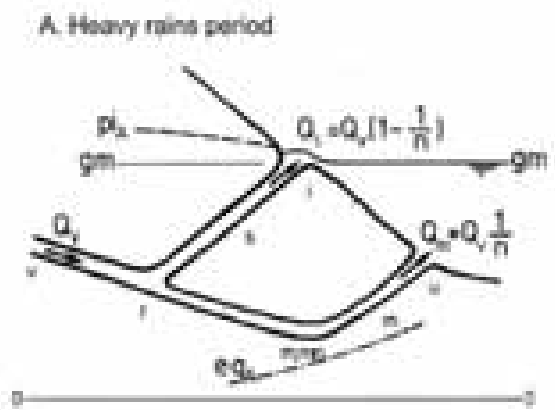

E. Ravy benod

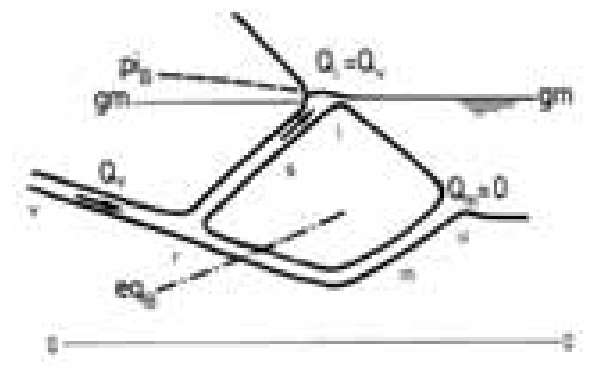

\section{Dry period}

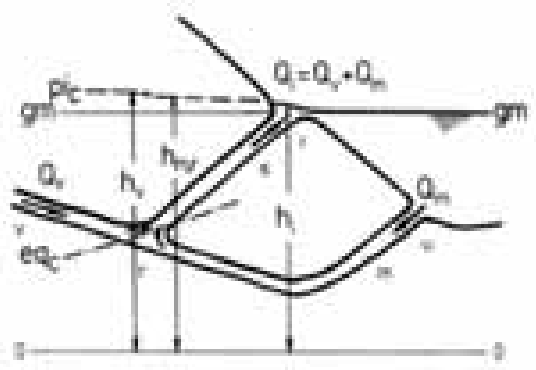

D. Very by peisod

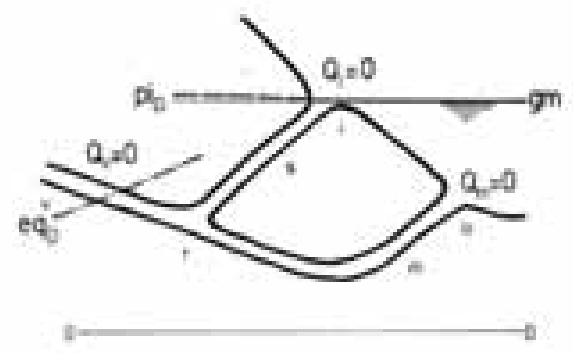

Fig. 7: Coastal spring with a siphon-like lower vein in a karst conduit flow aquifer, pi - piezometric surface, eq - equilibrium plane. Four Flow: Salinity regimes (Breznik 1989). 


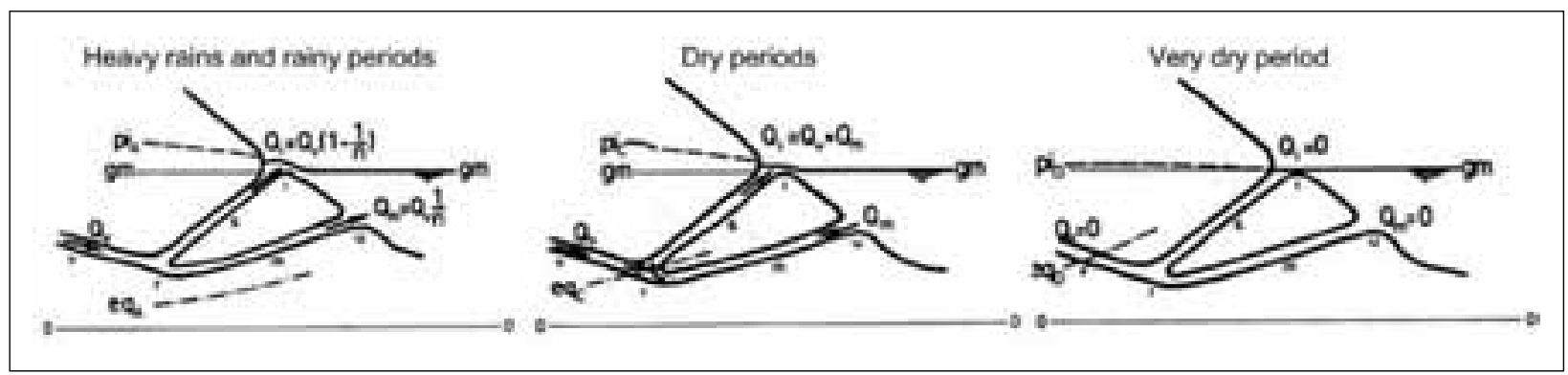

There are certainly very few springs with only 3 veins. Many pairs of primary and lower veins, with the branching of different depth, must be expected for a single spring. This explains the progressive contamination observed in the Almyros spring (Fig. 17). Many karst springs are fresh during high discharges. When the discharge decreases, the contamination begins. Let us suppose the discharge just before the beginning of the contamination is an equilibrium discharge $\mathrm{Q}_{\mathrm{eq}}$. In a karst vein is the equilibrium point, a place where the water pressures are equal from fresh and sea water sides. In a conduit-type-flow karst aquifer an equilibrium plane is an interrupted plane that connects all the equilibrium points in the veins. The position of the equilibrium plane determines the Flow: Salinity regime, and depends upon the elevation of the piezometric surface of fresh water in the vein-branching.
Fig. 8: Coastal spring with a rising lower vein in a karst conduit flow aquifer. Three Flow: Salinity regimes (Breznik 1989).

fresh water flow during a half million years and the yet effect lost.

In the Pleistocene period was the sea level till 120 $\mathrm{m}$ deeper and the Livadi bay, with a $30 \mathrm{~m}$ deep sea now, a karstic polje with a ponor and an outflow to the Sami coast. This paleo-primary vein is a lower vein now, and with a vein-branching at $100 \mathrm{~m}$ BSL we can easily explain the inflow of sea water into the "mill ponor" by the different densities of fresh and sea water. The $100 \mathrm{~m}$ deep column of sea water in the vein- branching provides a 2,5 $\mathrm{m}$ rise of the piezometric head, expressed by the head of fresh water. Out of this are $0,8 \mathrm{~m}$ losses of the head,

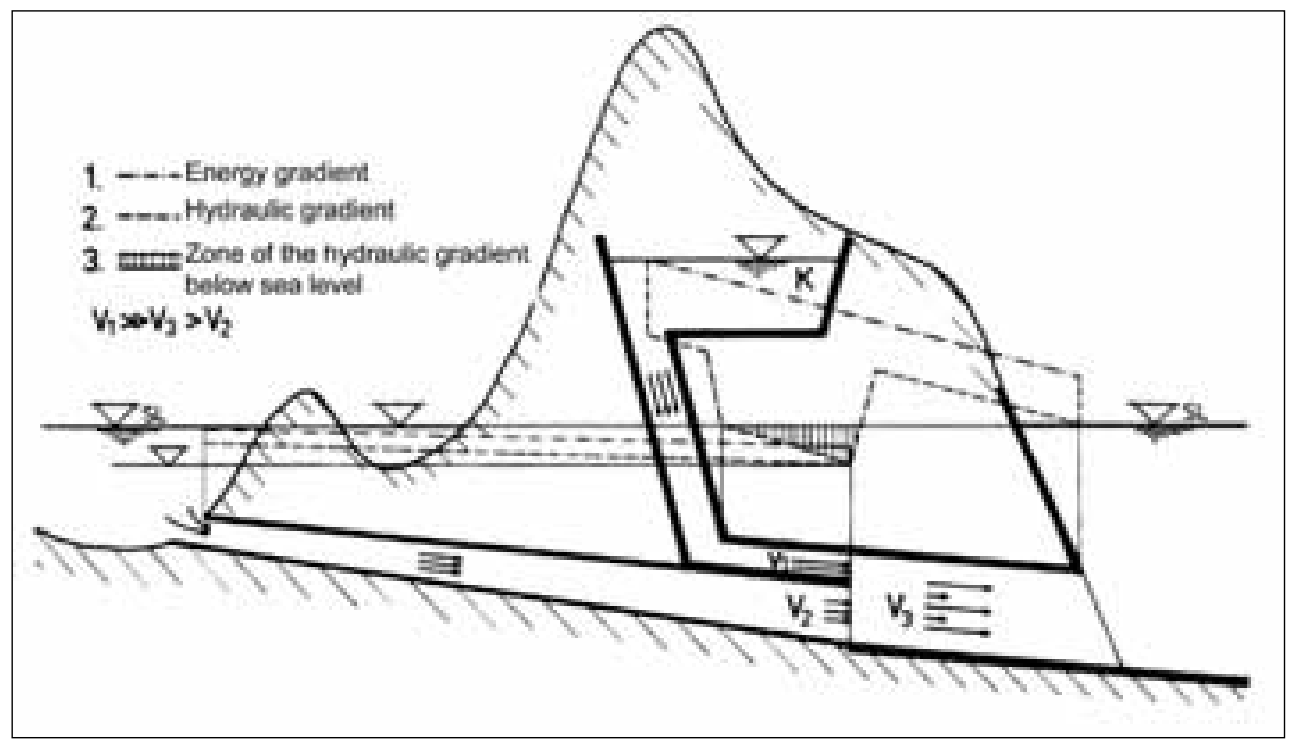

Fig. 9: "Sea water mill" on Kefalonia Island in Greece (Glanz 1965).

Glanz (1962) proposed a hydro-dynamic explanation of the famous "sea water mill" on the Kefalonia island in Greece by a yet flow and Maurin (1982) by a down fall of fresh water. We estimate that a nozzle needed for a yet flow would be dissolved and enlarged by 

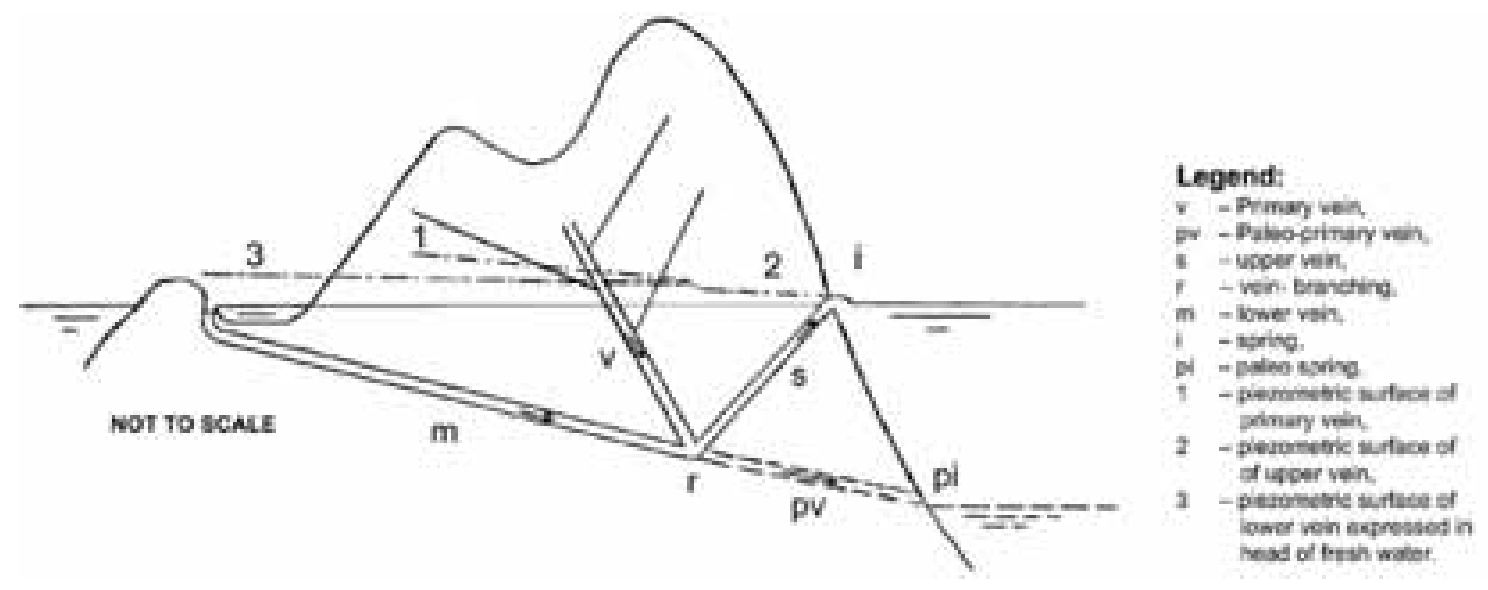

Fig. 10: "Sea water mill" on Kefalonia island in Greece, explained by the different densities principle (Breznik 1998, 2008).

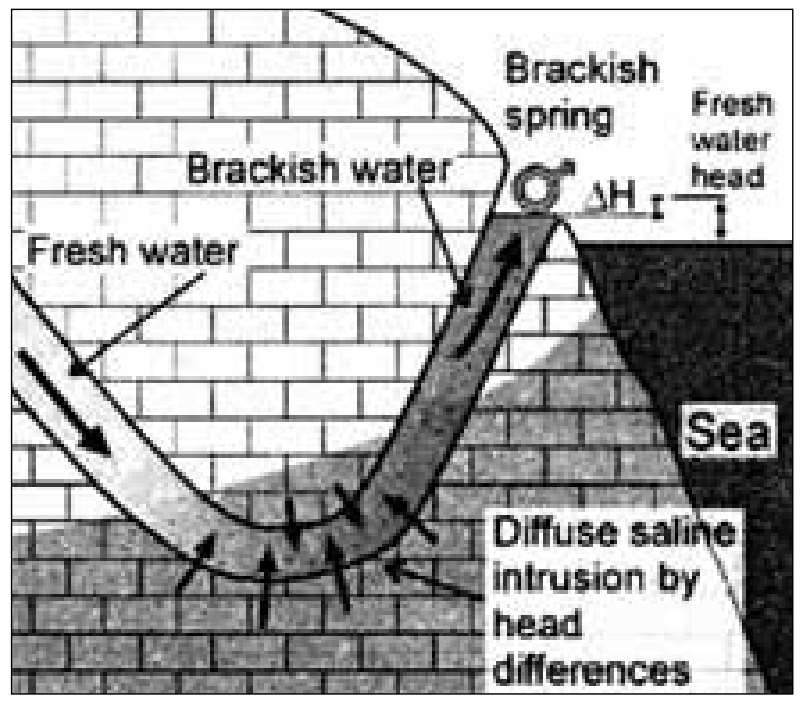

used for the flow of sea water through the $15 \mathrm{~km}$ long lower vein and $1,7 \mathrm{~m}$ is the denivelation of the sea level below the mill.

In the Arfib's one vein karst system, it would be difficult to explain a change from the outflow to the inflow of the estavelles during 1 to 2 days in the Jurjevo bay (Kuščer 1950). Also a 20 to $30 \mathrm{~m}$ high rise of the Almyros spring level would be an utopian proposal (Breznik 1998).

Fig. 11: Brackish spring contaminated by a diffuse saline intrusion in the main conduit (Arfib 2005).

\section{METHODS OF THE DESALINATION}

\section{INTERCEPTION METHOD}

The idea of this method is to capture fresh water inside the karst massif, outside the present sea water influence. Successful are the deep drilled wells Klariči in Slovenia, the system Zvir II with the duged and the drilled deep wells with $0,6 \mathrm{~m}^{3} / \mathrm{s}$ in Croatia, Gonies and Krousonas deep wells in Greece and elsewhere. Unsuccessful are due to overexploitation and salination the deep wells in Tylisos and Keri areas in Greece, many drilled deep wells in the Murgia, Salento and Taranto coastal aquifers in the southern Italy and in other places.

\section{ISOLATION METHOD}

The idea is to prevent the inflow of sea water into the karst massif by a diaphragm wall or a grout curtain. Positive examples are the grout curtains for the Žrnovica and Bačvice springs in Croatia and negative the grout curtain for the Tabačina spring in Montenegro, the diaphragm wall for the Malavra spring in Greece and the others.

\section{RISE-SPRING-LEVEL METHOD}

The idea of this method is to prevent the inflow of sea water by raising the spring level by a dam, a grout curtain 
or a diaphragm wall. This method could succeed only in an aquifer with a siphon shaped lower vein. But also there a too high rise could induce the losses of fresh water through the lower vein into sea, shown on Figure 7 from the period $C$ by a human rise of the spring level to the period $\mathrm{B}$, and not by a to high rise, to the period $\mathrm{A}$.

\section{METHOD OF THE REDUCED PUMPING DISCHARGE}

In many coastal aquifers a reduced pumping discharge could maintain a low salinity of water in the dry periods. A reduction of pumping prevents the salination of the drainage galleries Kovča - Zaton, Roman wells (Bakar, Trogir) and Šipan in Croatia during the dry periods (Biondić, 2005) and elsewhere.

\section{CASES}

\section{KRAS COASTAL AQUIFER IN NORTHERN ADRIATIC}

The surface of the Kras aquifer is $730 \mathrm{~km}^{2}$, with a larger part in Slovenia and a coastal outflow area in Italy. Recharged is by the infiltration of the precipitations of $1100 \mathrm{~mm} /$ year, by the Notranjska Reka with $5 \mathrm{~m}^{3} / \mathrm{s}$ (lowest measured: $0,18 \mathrm{~m}^{3} / \mathrm{s}$ only) inflow in the ponors near Škocjan, by $1 \mathrm{~m}^{3} / \mathrm{s}$ inflow in the ponors of the Vipava River and by the Isonzo River ponors buried beneath

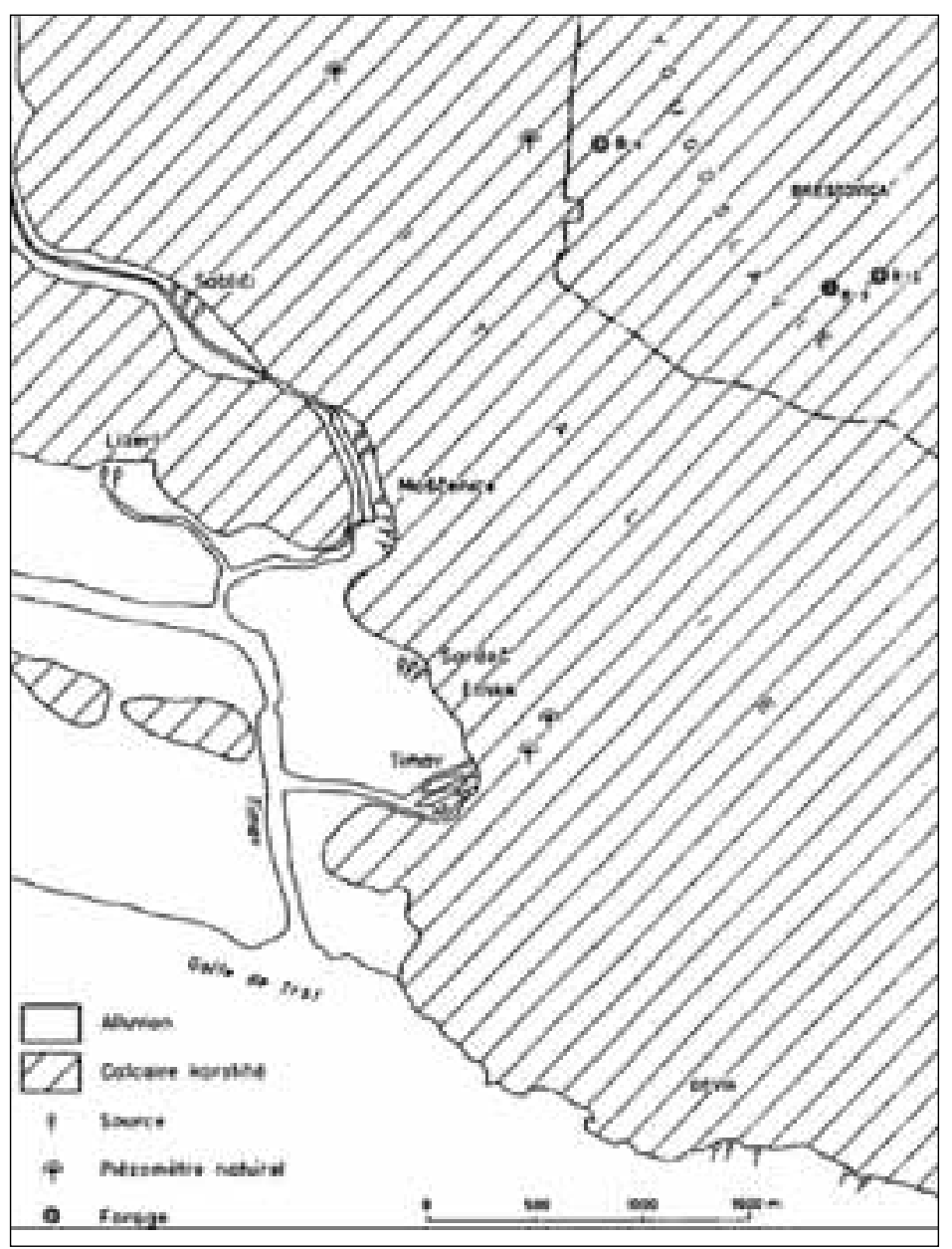

gravel along the Doberdo karst. The mean outflow is $35 \mathrm{~m}^{3} / \mathrm{s}$ in rainy periods and $10 \mathrm{~m}^{3} / \mathrm{s}$ in dry periods - the majority of it in the Timavo springs area, a small part of $0,2 \mathrm{~m}^{3} / \mathrm{s}$ out of small coastal springs and an important out of the estavelles in the Duino sea which swallow sea water in the dry periods (Petrič 2005, Steinman 2007, Breznik 2006).

In the Klariči pumping station 3 deep wells, VB-4 from $16 \mathrm{~m}$ ASL to $54 \mathrm{~m} \mathrm{BSL}$, were drilled near the B4 borehole (Krivic 1982). The Klariči station with a limited pumping discharge of $250 \mathrm{l} / \mathrm{s}$ supplies drinking water to the Kras region with 25.000 people since 1986 and till $130 \mathrm{l} / \mathrm{s}$ of water is flown to the Slovene coastal region with 40.000 people since 1994. Coastal region has also the Rižana karst spring with only $200 \mathrm{l} / \mathrm{s}$ in the dry periods (Petrič 2005).

The level of the main Timavo spring was risen about 1,5 $\mathrm{m}$ ASL with a small weir and was the main water source for the Trieste town until 30 years ago.

The lowest static water level in Klariči was $2,5 \mathrm{~m}$ ASL. Karst groundwater pumped in Klariči is recharged in the eastern part from the Kras during rainy periods and from Isonzo river groundwater mainly during dry periods. Isonzo-Soča river groundwater infiltrates in paleo-ponors buried beneath gravel in the NW part of the Doberdo karst plateau. Three large estavelles, about $1 \mathrm{~km}$ from the Duino coast, are the outflow of this water in rainy periods, and swallow sea water in dry periods. They were important springs of a part of the Isonzo River in a dry Upper Adriatic land during the Lower Pleistocene (Šegota 1968). The estavelles indicate a geologic border on sea bottom between the karstified carbonate rocks of the

Fig. 12: Outflow area of Kras aquifer (Krivic 1982). 


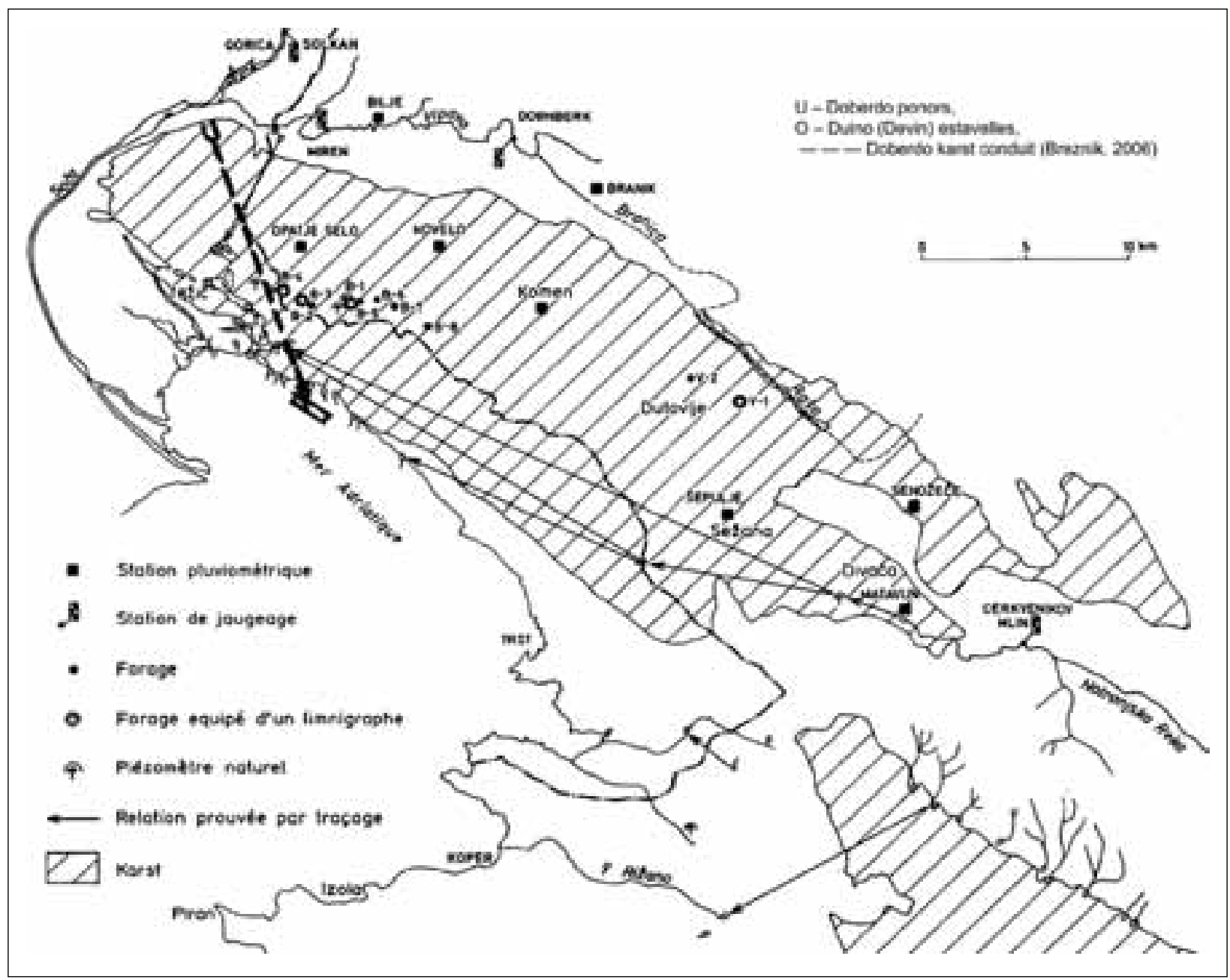

Fig. 13: Doberdo karst conduit (Breznik 2006), Kras aquifer (Krivic 1982).

Cretaceous against impervious Flysh sediments of the Eocene.

How sustainable are good quantity and quality of this water? We explain these in Klariči station at $4 \mathrm{~km}$ from the coast and water pumped out a karst conduit at $26 \mathrm{~m}$ below sea level, by a human rised level of the Timavo spring, by a large outflow of Timavo springs of $10 \mathrm{~m} 3 / \mathrm{s}$ in dry periods, by a shallow karstifications due to an impermeable Flysh barrier on sea bottom of $20 \mathrm{~m}$ BSL at the outflow of the estavelles, by a low permeability of the karst rock mass of conduit and by a chance of an absence of the human pollution until now.

Land reclamations in the Timavo springs area, $f$. e. for new storage places of the shipyard, with drainage ditches and a destruction of the small weir would lower water level there and also in the Klariči station and could induce a salination of water. Mercury ore was excavated in the Idrija mine, which is closed now, for 500 years. Idrijca and Soča rivers transport $1500 \mathrm{~kg}$ of $\mathrm{Hg}$ to sea every year. In water pumped out from VB4 well in Klariči 1,2 ng of Mercury was measured. This very small quantity of $\mathrm{Hg}$ is not harmful for the health, but could accumulate in the cave deposits (Doctor et al. 2000). A third thread could be a human pollution as there are no protection areas.

We propose to pump $2-3 \mathrm{~m}^{3} / \mathrm{s}$ of the Rižana river to a $250 \mathrm{~m}$ higher large Pinjevec storage reservoir in the rainy period and to flow it out in the dry periods to Rižana with an existing drinking water treatment plant and towards the pipeline from the Gradole spring in Croatia, where the contract of an obligatory water supply has expired in 2005. The elevation of water in Pinjevec reservoir at about $310 \mathrm{~m}$ ASL enables always a gravitational outflow to the supply system without electricity. In the dry periods, could be the lower layer of euthropic water of Pinjevec reservoir released, in cascades enriched with oxygen and used for the irrigation of Dragonja and Sečovlje plains, what is an 25 years old proposal. The mixing of reservoir water, with the aim to prevent euthrophication, will not be necessary. Two inflows of the 


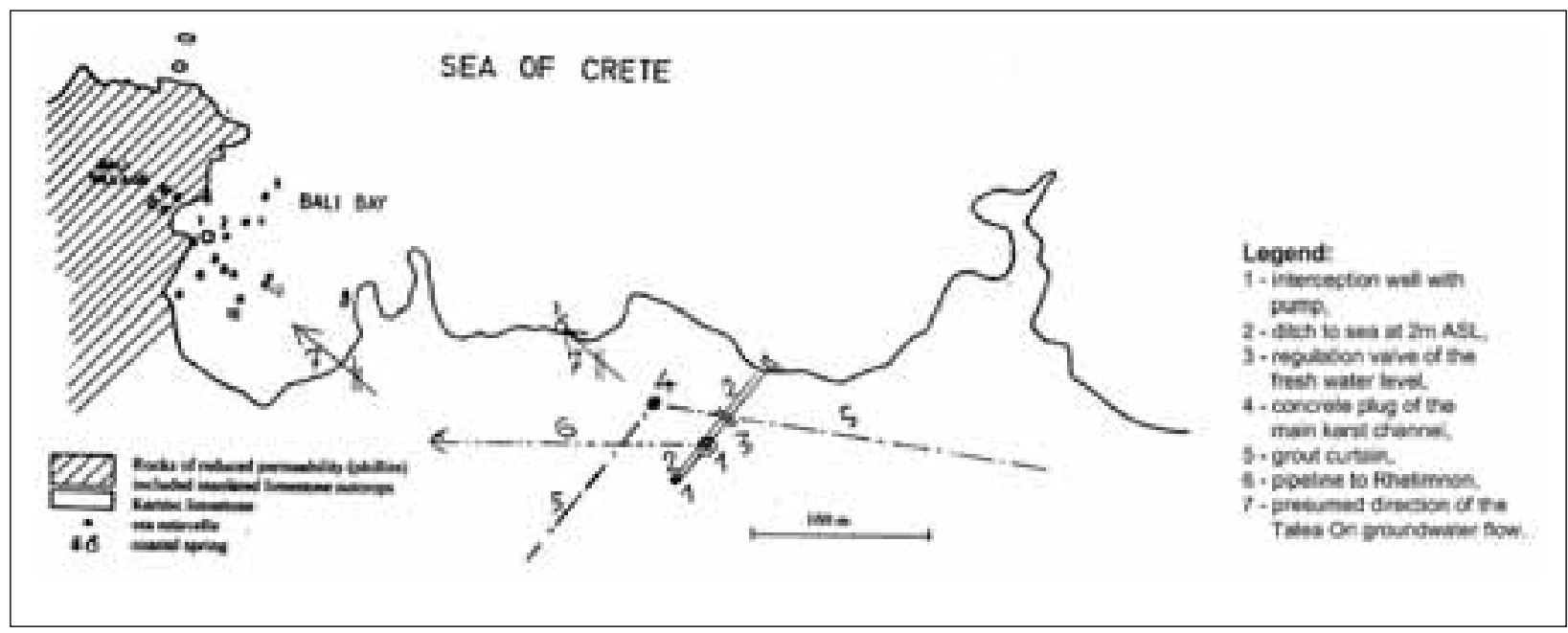

Fig. 14: Structures for the desalination of the Bali bay springs and estavelles (2008). Bali bay springs and estavelles (Economopoulos 1983).

water, from the northern Rižana and southern Dragonja directions, into the coastal water supply system, will increase its safe operation.

The proposed, and probably already designed new Padež storage reservoir, with a $35 \mathrm{~km}$ long new pipeline, will be "on the other side of the hill" and will need a $250 \mathrm{~m}$ high pumping, all around the year. The electrical energy is however not always at disposal, as the recent, some days lasting "black outs" in California, New York and Western Europe have demonstrated. Padež reservoir will need also an artificial mixing of water with the aim to prevent the euthrophication.

\section{BALI BAY COASTAL AQUIFER IN GREECE}

The catchment area of the Bali bay aquifer is the Talea Ori karstic massif with $50 \mathrm{~km}^{2}$. In the wet period fresh water flows out of coastal springs and estavelles (Economopoulos 1983). We explored Syphona spring No 3 at $12 \mathrm{~m}$ BSL with an outflow of some $\mathrm{m} 3 / \mathrm{s}$ of brackish water with around $10.000 \mathrm{mg} / \mathrm{l} \mathrm{Cl}$ in the late summer of 1970. Divers led by P. Economopoulos were hampered by poor visibility in the outflow funnel of the spring, what indicates the mixing of fresh and sea water there (Breznik 1998). French divers studied estavelles-ponors in the Bali bay in late summer 1991. At a depth of $12 \mathrm{~m}$ there were a number of smaller and 3 larger estavelles which swallow more than $1 \mathrm{~m}^{3} / \mathrm{s}$ of sea water (Barbier et al. 1992). Position of estavelles in the wet period and the outflow of the Syphona spring in the dry period indicate the direction of the Talea Ori underground flow. Geophysical methods: Map of electrical potentials "mise à la masse" with one electrode in the Syphona spring and the Very low frequency (VLF) of radio waves (Mueller et al. 1986) should determine the position of the main Talea Ori water conduit to the Syphona spring.

The next exploration work are: capture groundwater of the conduit with drilled interception wells; excavate a ditch with a regulation valve from the interception wells to sea at $2 \mathrm{~m} \mathrm{ASL}$; plug with a concrete and a grouting the conduit between the interception wells and the Syphona spring; construct a one row grout curtain, distance of the boreholes $2-3 \mathrm{~m}$, till $60 \mathrm{~m}$ and $120 \mathrm{~m}$ BSL; rise the water level by the regulation valve to $5 \mathrm{~m}$ and $10 \mathrm{~m}$ ASL; find out possible water losses along the coast by registration of new springs and by the temperature logging of coastal water from a helicopter; construct additional grout curtains if necessary.

We evaluate there is a $70 \%$ probability to desalinate 0,5 to $1,0 \mathrm{~m}^{3} / \mathrm{s}$ of the Talea Ori groundwater that could be used in the Rhetimnon city area.

\section{ANAVALOS-KIVERI COASTAL SPRINGS IN GREECE}

Tripoli and other poljes are drained by coastal and submarine springs along the NE coast of the Peloponnesus peninsula in Greece (Gospodarič et al. 1986). A $180 \mathrm{~m}$ long semicircular dam was founded on calcareous breccia at $10 \mathrm{~m} \mathrm{BSL}$ and with a top at $4 \mathrm{~m} \mathrm{ASL}$ in 1968. We visited the place in the spring 1969. The sluices of the dam were open and a river of greenish color flowed out, that clearly differed from the blue sea. We observed a typical circle of the groundwater flowing out of an estavelle at a distance about $0,5 \mathrm{~km}$.

Prof. Ständer from Germany, who proposed the isolation of springs, answered in a letter that a major development was achieved by the isolation of the spring's area with the dam, thereupon the salinity decreased to 200 - 


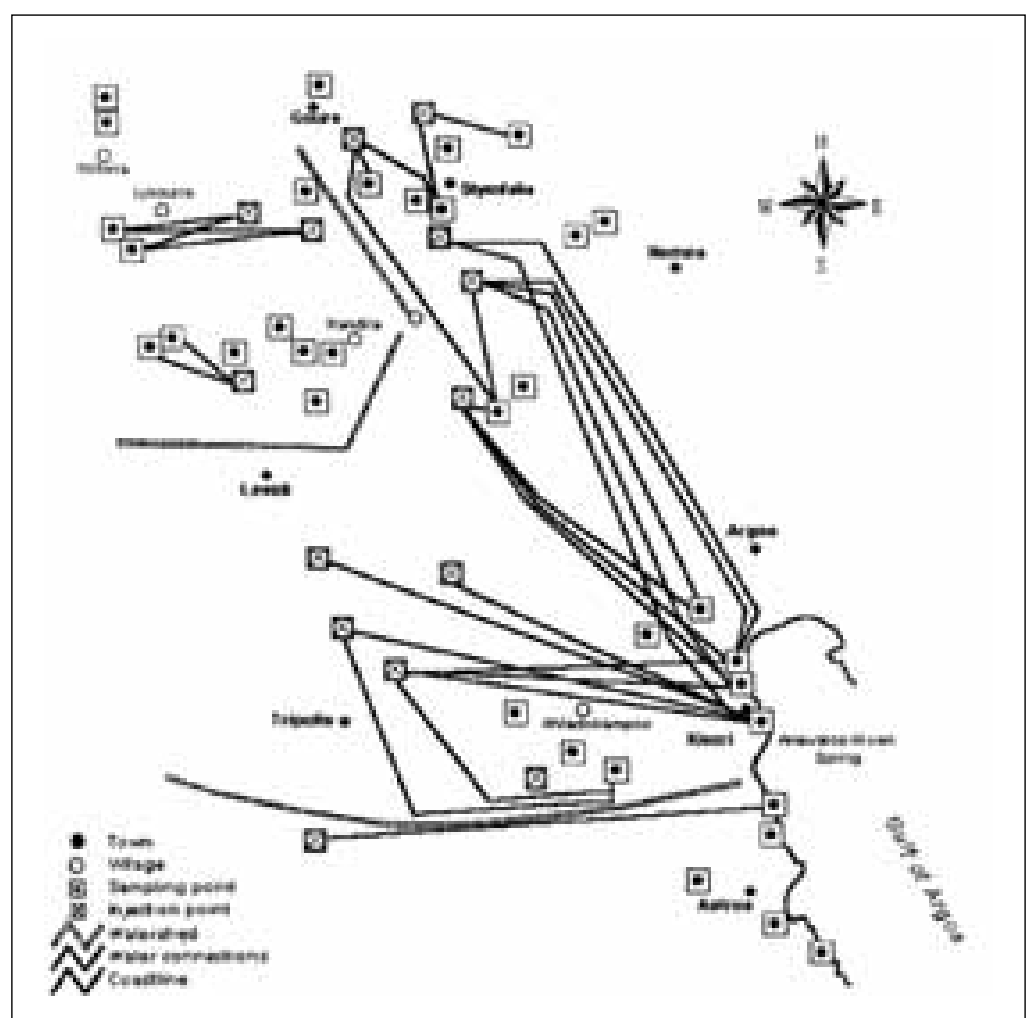

Fig. 15: Underground water connections of the Peloponnesus, found by tracing experiments (Gospodarič and Leibungut 1986).

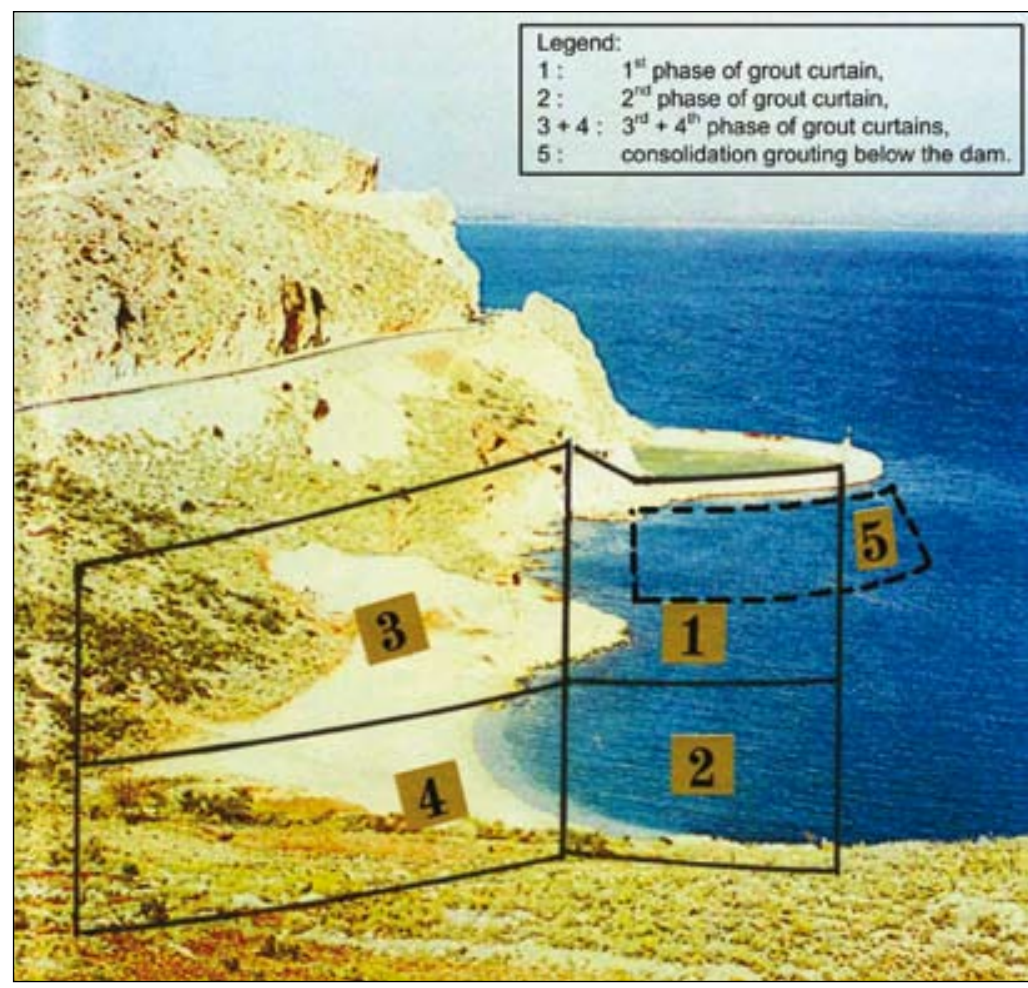

Fig. 16: Kivery dam. Desalination structures proposed (2008, photo Breznik 1969).
$300 \mathrm{mg} / \mathrm{l} \mathrm{Cl}$. A second phase of the development was completed with a rise of the pool level to $3 \mathrm{~m}$ ASL at a discharge of $12 \mathrm{~m}^{3} / \mathrm{s}$ and the inflow of sea water stopped (Ständer 1971). A photo shows a present outflow of groundwater outside the Kiveri dam (Lambrakis 2005). The average springs discharge is $6 \mathrm{~m}^{3} / \mathrm{s}$. During the irrigation periods $1955-1990$ the groundwater quality worsened due to the overpumping and the sea water intrusion (Tiniakos et al. 2005).

A short analysis of the available data indicates that the isolation of the Kiveri springs against sea water inflow is not completed. A dam founded on very karstified breccia without a consolidation of the limestone mass and without a grout curtain, is not a completed structure. Prof. Ständer estimated the depth of the karstification at $90 \mathrm{~m}$ BSL. We suppose this depth to be either $30 \mathrm{~m}$ deeper of the sea bottom at the estavelle observed in 1969 , or $30 \mathrm{~m}$ deeper than a $120 \mathrm{~m}$ BSL deep sea level in the Pleistocene if the Argos bay is deep enough.

We propose to prevent the sea water inflow by a grout curtain. The exploratory works should be done in phases. First phase: boreholes drilled at a distance of $4 \mathrm{~m}$ along the crest of the dam and grouted to a depth of $65 \mathrm{~m} \mathrm{BSL}$, then consolidation grouting of the karstified breccia below the dam from $10 \mathrm{~m}$ to 35 $\mathrm{m}$ BSL. Second phase: boreholes, in between boreholes of the first phase, drilled and grouted till $130 \mathrm{~m}$ BSL. Third phase: grout curtain below the road extended for $200 \mathrm{~m}$ on both sides of the dam. Forth phase: additional grout curtains behind the smaller springs to the north if needed. In all this exploratory phases a testing with a rise-spring-level to be made, the results analyzed and the next phases adjusted. A $4 \mathrm{~m}$ rise enables the existing dam.

This is a general proposal for exploration activities and they should be adapted to the partial results obtained. A final success with a $70 \%$ probability is to desalinate the spring's water to $50 \mathrm{mg} / \mathrm{l}$ $\mathrm{Cl}$ in dry periods. 


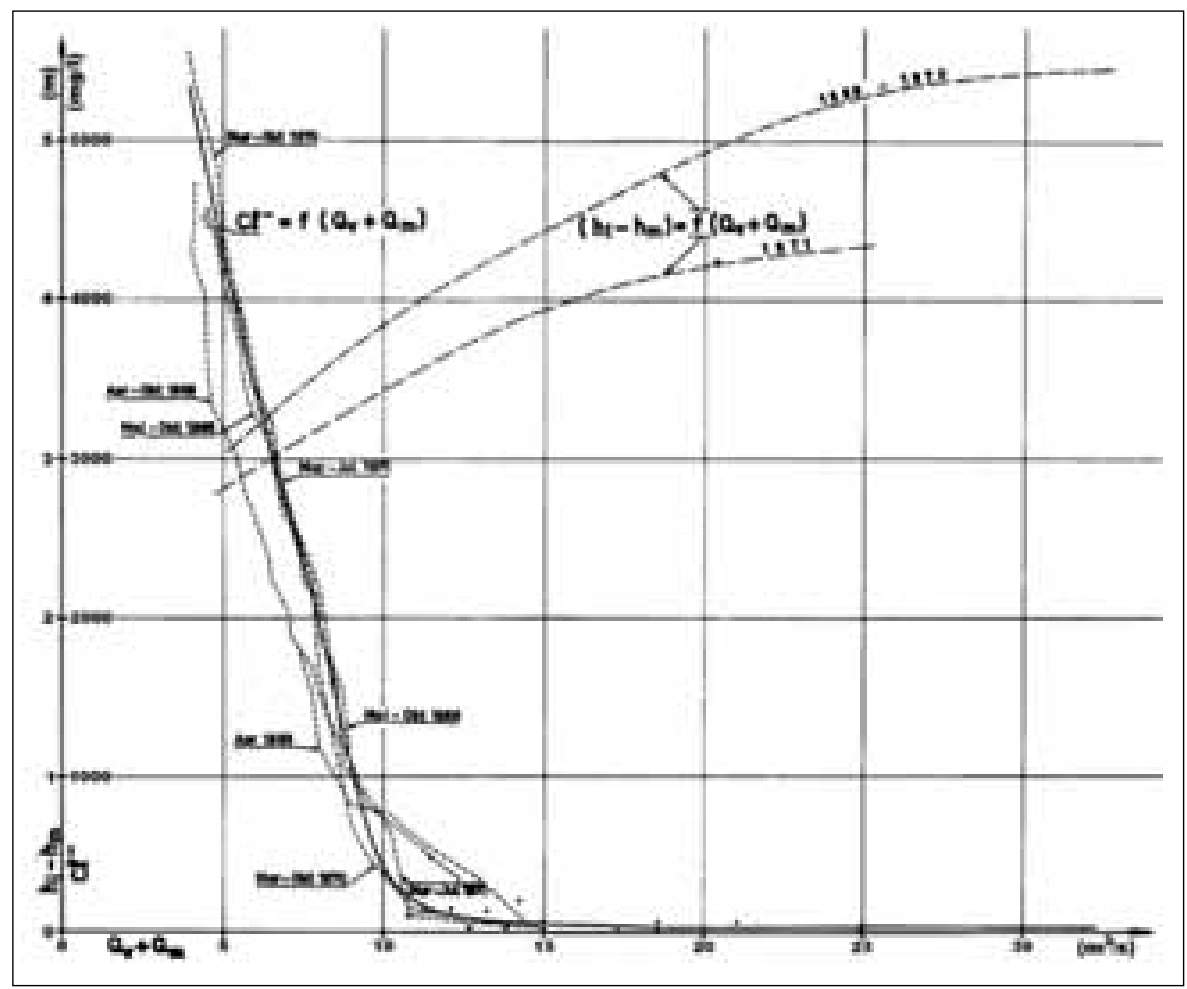

Fig. 17: Discharge-salinity curve of the Almyros water (Ré 1968).

All the veins are in Mesozoic limestone and the lower veins below the Festos-Iraklion graben filled with Neogene deposits. This spring was investigated by the United Nations - UNDPFAO and Greek Government in the years 1967-1972. Between the spring and sea coast 15 deep boreholes, with a mean depth of $240 \mathrm{~m}$, were drilled, with the aim to find, and to seal with a grout curtain, a conduit with sea water inflow. This conduit is not between sea and the spring, but is below Neogene deposits at about $800 \mathrm{~m}$ BSL and about $14 \mathrm{~km}$ long.

Almyros spring has a mean discharge of $8 \mathrm{~m}^{3} / \mathrm{s}$, a temperature of water $16^{\circ} \mathrm{C}$ and had a tritium content of $45 \mathrm{~T}$. U. of samples taken in August 1969, analyzed at IAEA in Vienna. Precipitations at Rhodos island had 1100 T.U. in

\section{ALMYROS IRAKLIOU BRACKISH SPRING IN GREECE}

The characteristic of this spring, at $1 \mathrm{~km}$ from the sea coast, with many primary veins, of a $300 \mathrm{~km}^{2}$ karstic recharge area and with very deep vein-branchings at differed depths, is a very slow increase of the salinity during a decrease of the discharge (Ré 1968).

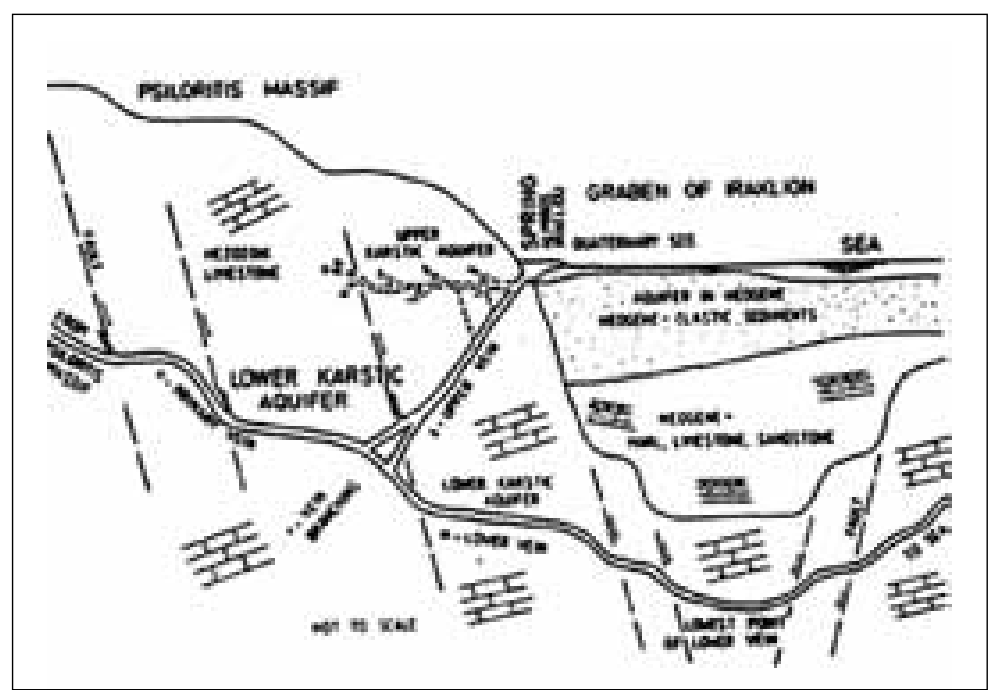

Fig. 18: Almyros Irakliou brackish spring. Main aquifers of the Psiloritis and Keri massifs and of the Iraklion graben (Breznik 1984, 1998). 1963, 200 T.U. in 1964 and 50 T.U. in 1969, while in Ljubljana 120 T.U. in 1975, what confirms a large volume of the Psiloritis underground storage and a slow, many years lasting outflow of precipitations. A week aquifer in Neogene deposits had a discharge of $0,12 \mathrm{~m}^{3} /$ $\mathrm{s}$, a temperature of water $19-20^{\circ} \mathrm{C}$ and $19-13 \mathrm{~T}$. U. in the same period (Breznik 1971).

We proposed to explore the desalination of the Almyros spring by the isolation, rise-spring-level and interception methods. A $10 \mathrm{~m}$ rise of spring level was proposed (Breznik 1971). A new dam was constructed (1976) and spring level was rised at 10 m ASL for some month in 1977 and 1987. Spring water remained brackish (negative result) but the discharge diminished only slightly and no estavelles appeared in the Iraklion Sea (positive results). We concluded that a higher elevation of the level should be determined by a winter test with a larger discharge of water (Breznik 1978), proposed a 20 to $30 \mathrm{~m}$ rise (1984) and calculated a $28,76 \mathrm{~m}$, however with uncertain data (1989). 


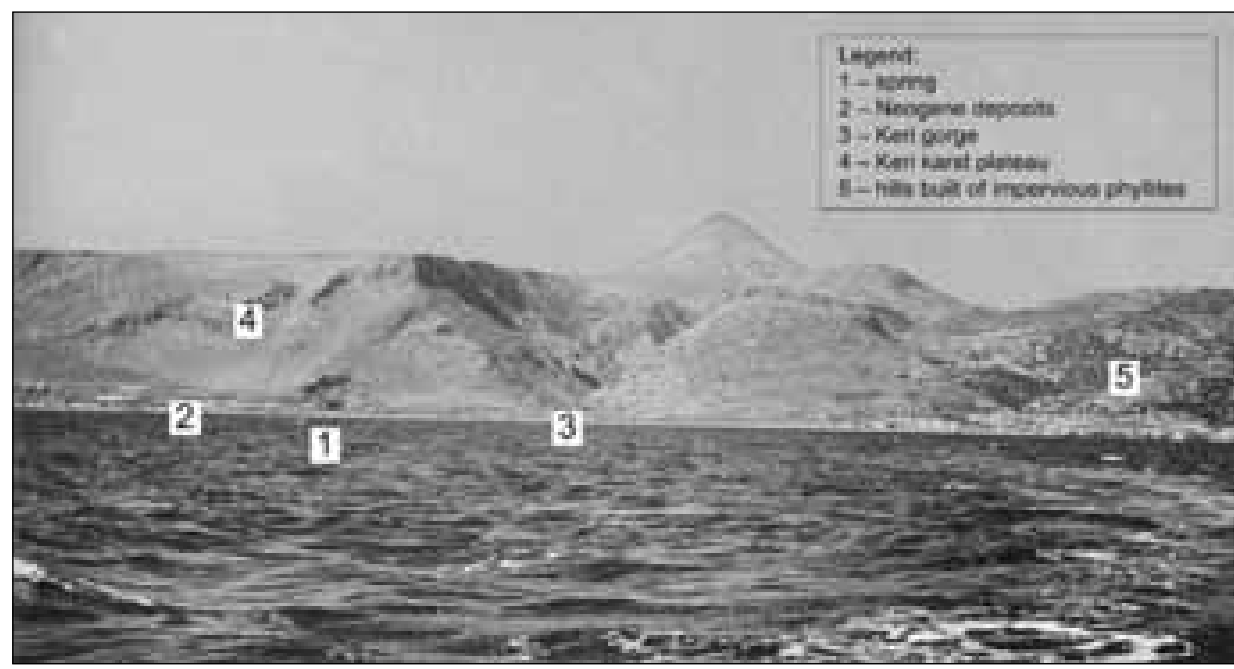

Fig. 19: View of the Almyros Irakliou spring area (photo Breznik, 1970). with 2 table valves; drill interception wells into the main karst conduit till $30 \mathrm{~m} \mathrm{BSL}$; excavate 2 bottom outlets, of $5 \mathrm{~m}^{2}$, with reinforced concrete lining, with valves at the outlets; seal the conduit with a concrete plug and a consolidation grouting. Raise the spring level, register the salinity and locate water losses. Second phase: construct a grout curtain of one row boreholes at a $4 \mathrm{~m}$ distance, till a depth of 80 $m$ BSL. Raise the spring level and register the results. Third and other phases: condense and extain the grout curtain, with boreholes at $2 \mathrm{~m}$ distance, till a depth of $120 \mathrm{~m} \mathrm{BSL}$, construct a small dam around an expected overflow karst spring in the Keri ravine. Raise the spring level to $25-35 \mathrm{~m}$ ASL. When the salinity is below $50 \mathrm{mg} / \mathrm{l} \mathrm{Cl}$ and losses of water are small the exploration phases are completed. We expect, with an $80 \%$ probability, a safe yield of fresh water of about $2 \mathrm{~m}^{3} / \mathrm{s}$ in dry periods.

The exploration phases with testing are:
First phase: excavate a shaft, of $8 \mathrm{~m}$ diameter, with
reinforced concrete lining, from surface to $5 \mathrm{~m}$ ASL,
The structures for the exploitation of fresh water are: Spillway for the high water outflow, small hydropower station for the regulation of the required water level for the desalination and for the production of the electricity, fresh water pipeline to Iraklion. Hydropower stations regulate the level of water in the irrigation canal along the Durance River in France. Rise-spring-level method could desalinate also ground-

Fig. 20: Structures for the exploration phases of the desalination of the Almyros brackish spring by the rise of the spring level with an underground dam (2008). Map of karst conduit - Babier et al. 1992. 
water of the Keri, Tylissos and other low altitude areas. The existing Iraklion power station could be cooled by hyperbolic cooling towers used in Europe, or by sea water pumped out of deeper layers, used for cooling nuclear power stations in Japan. This unique desalination plant will be very attractive for tourists in Crete and should be economically exploited by the presentation of the underground hydrogeology, of the desalination structures and the restoration of the old scenery with mills.

\section{Interception method of development}

In the years 1968-1971 were the piezometric levels of fresh water in the Gonies area in boreholes at about $44 \mathrm{~m}$ ASL at the distance of $8 \mathrm{~km}$ from the Almyros spring and in the Koubedes-Tylissos area in the boreholes at about $29 \mathrm{~m}$ ASL, at the distances 3-4 km (Breznik 1971, 1973). The municipal DAYAH Company had drilled 40 deep wells in the areas Keri, Tylissos, Gonies and Krousonas (at $13 \mathrm{~km}$ ) since 1987. In the year 2000 fresh water was pumped out of 17 deep wells (Arfib 2000). A normal consequence of a pumping many years out of coastal aquifers is a decline of the piezometric surface and the inflow of sea water. In Tylissos area the piezometric surface declined from about $29 \mathrm{~m}$ in seventies to about $15 \mathrm{~m}$ in 1997 and induced a salination of wells (Monopolis et al. 1997, 2005).

The important question is now; could water of wells in the Gonies and Krousonas areas remain fresh? Groundwater of these areas flows to Almyros spring through a very deep vein-branching at 800-1000 m BSL, where is a fresh water outflow and a sea water inflow which depends upon the piezometric surface of the fresh water. An expected overpumping of the Gonies-Krousonas wells, due to the loss of the Keri-Tylissos salinated wells, will lower the fresh water piezometric surface and induce a sea water inflow. Only moderate pumping yields could prevent the salination of this water. An over pumping of Malia wells will have similar consequences.

\section{CONCLUSIONS AND RECOMMENDATIONS}

Many desalination methods were proposed and many scientific papers published but, the important Greek springs: Bali, Kiveri and Almyros Irakliou, are still brackish, after 30 years of attempts. In a karst underground are so many unknown data, needed for a mathematical groundwater model, that the results are not reliable. We propose to achieve the desalination with physical-field tests: by the isolation method for the Bali and Kiveri springs with grout curtains and by the rise-spring-level method for the Almyros Irakliou spring with an underground dam. We estimate there are $70-80 \%$ probabilities of the success.
The Pinjevec storage reservoir with 20 - 30 millions m3 of fresh water pumped out of Rižana river, could solve water shortage of SW Slovenia. The Intergovernmental Panel on Climate Change (IPCC) warns about still smaller precipitations and higher temperatures in the Southern Europe in the future.

We reserve author's rights for the desalination methods and structures.

\section{ACKNOWLEDGMENTS}

We thank to the Governments of Slovenia, Croatia, Montenegro, Greece, India and Turkey for the presentation of their unpublished investigation results. 


\section{REFERENCES}

Arfib, B. \& G. de Marsily \& J. Ganoulis, 2000: Pollution by seawater intrusion into a karst system: New research in the case of the Almyros source (Heraklio, Crete, Grece). - Acta carsologica, 29/1, 15-31, Ljubljana.

Arfib, B. \& G. de Marsily, 2004: Modelling the salinity of an inland coastal brackish karstic spring with a conduit-matrix model. - Water Resour. Res. 40(11), 1-10, Washington.

Arfib, B. \& O. Bonacci, 2005: Particular aspects of discharge in coastal karstic aquifers. Groundwater management of coastal karstic aquifers. - EUR 21366 En, COST Action 621, 87-104, Brussels.

Arfib, B., G. de Marsily \& J. Ganoulis, 2007: Locating the zone of saline intrusion in a coastal karst aquifer using springflow data. - Ground Water 45(1), 28-35.

Badon-Ghyben, W., 1901: Nota in verband met de voorgenomen putboring nabij Amsterdam. - Tijdschrift van het Koninklijk Institut van Ingenieurs, The Hague.

Barbier, J. L. \& R. Therond \& H. Paloc, 1992: Source d'Almyros d'Heraklion, Synthese des etudes depuis 1988, Rapport general. - Unpublished report of GERSAR to the Greek Ministry of Agriculture, p. 65, Paris.

Bidovec F., 1965: The hydrosystem of karstic springs in the Timavo basin. - UNESCO - IHD Symp. on Hydrology of Fractured Rocks, 263-274, Dubrovnik.

Biondić, B. \& G. Gunay \& P. Marinos \& A. Panagopoulus \& L. Potié. \& G. Sappa \& A. Stefanon, 2005: Protection and remediation practices. - EUR 21366 En, COST Action 621, 231-241, Brussels.

Biondić, B., 1988: Tapping and protection of underground water in the Adriatic region related to the new conception of the structure of Dinarides. - Proc. Karst Hydrog. Karst Envir. Prot., 187-193, Guilin.

Bonacci, O. \& T. Roje-Bonacci, 1997: Sea water intrusion in coastal karst springs: example of the Blaž Spring. - Hydrol. Sci. J. 42(1), 89-100, Oxford.

Bonifay, E., 1974 in Potie, L. \& J. Ricour, 1974: Etude et capitage de résurgences d éau douce sous $\sim$ marines. - Ressources en Eau, 5-27, Paris.

Borelli, M. \& B. Pavlin, 1965: On the underground water leakage from the storages in Karst region. Karst storages Buško blato, Peruća and Kruščica. - UNESCO - IHD Symp. on Hydrology of Fractured Rocks, 32-63, Dubrovnik.
Bosi et al. 1996: Eustatic curve related to Quaternary and curve of max regressions. - EUR 21366 En, COST Action 621, p. 165, Brussels.

Breznik, M., 1971: Geology and Hydrogeology of the Almyros spring area. - Unpublished Tech. Note No. 103 of UN-FAO presented to Greek Gov., 1-94, Iraklion.

Breznik, M., 1973: Nastanek zaslanjenih kraških izvirov in njihova sanacija. The Origin of Brackish Karstic Springs and their Development. (Summary of the Doctor of Geology Thesis, 1972). Geologija, 16, 83186, Ljubljana.

Breznik, M., 1977a: Exploration and Development of Coastal and Submarine Brackish Springs in Turkey. - Unpublished report of UN-OTC presented to Turkish Gov., 1-35, Ankara.

Breznik, M., 1977b: Test to Raise the Water-level of the Almyros Irakliou Spring - Evaluation of Results of the 1977 Summer Test. - Unpublished report presented to Greek Gov., 1-11, Iraklion.

Breznik, M., 1978: Mechanism and Development of the Brackish Spring Almyros Irakliou. - Ann. Geol. Des Pays Hell., 29-46, Athens.

Breznik, M., 1979: The Reliability of and Damage to Underground Dams and Other Cut off Structures in Karstic Regions. - $13^{\text {th }}$ Int. Congr. On Large Dams, New Delhi, 4, 57-79, Paris.

Breznik, M., 1981: Groundwater hydrology and hydraulics - Flow in aquifiers. - International course: Water resources engineering, 1-54, Beograd.

Breznik, M., 1984a: Bansagar project - Protection of Kuteshwar limestone deposit. - Unpublished report presented to the Central Water Commission of Government of India, 1-15, New Delhi.

Breznik, M., 1984b: Development of the Almyros Irakliou brackish spring. - Unpublished report presented to the Greek Gov., 1-34, Ljubljana.

Breznik, M., 1984c: Exploration of the Bali brackish spring. - Unpublished report presented to the Greek Gov., 1-5, Malia.

Breznik, M., 1984d: The safety and endurance of the old dams of Idrija. - Int. Conf. Safety of Dams, 133-139, Coimbra.

Breznik, M., 1985a: Exploration, design and construction of cut offs in karstic regions. - $15^{\text {th }}$ Int. Congr. on Large Dams, Lausanne, 58(3),1111-1129, Paris.

Breznik, M., 1985b: Neka iskustva o bušenju bunara u krasu. (Some experiences on drilling wells in the karst, in Serbo-Croatian) - Scient. Conf. 'Voda i kršs, 159-164, Mostar. 
Breznik, M., 1985c: Perspektiva in problematika izkoriščanja podzemnih voda. (Perspective and problematics of ground water exploitation, in Slovene) - Acta hydrotechnica, 3-45, Ljubljana.

Breznik, M., 1986: Programme of the investigation of the influence of the Mavčiče reservoir on the environment. $-13^{\text {th }}$ Yug. Cong. on Large Dams, 191-195, Mostar.

Breznik, M., 1988: Safe yield of wells in arid areas based on ground water balance. Regional workshop for the preparation of the international map of Africa, sheet 2 (north central Africa), p. 7, Zagreb.

Breznik, M., 1989: Explorations, mechanism and development of brackish karst spring Almyros toy Irakleioy. - Unpublished report presented to the Greek Ministries of Agriculture and Research and Technology and Universities of Athens and Crete, 1- 59, Ljubljana.

Breznik, M., 1990a: Development of brackish karstic spring Almyros in Greece. - Geologija, 31, 32, 555576, Ljubljana.

Breznik, M., 1990b: Ogroženost podtalnice. (Endangering of Ground Water, in Slovene) - Ujma 4, 111 116, Ljubljana.

Breznik, M., 1993a: Evaluation of exploration results and development possibilities by underground dam and other methods of karst spring Almyros Irakliou. - Unpublished report presented to the Greek Gov. - Eastern Crete Development Organisation, 1-90, Ljubljana.

Breznik, M., 1993b: Exploitation of Underground Water Reservoirs in Karst. - Int. Symp. on Water Res. in Karst, 1-13, Shiraz.

Breznik, M., 1996: Vodni viri za Obalo in Kras Slovenije. (Water sources of Coastal Region and Slovenian Karst, in Slovene) - UL-FGG, p. 133, Ljubljana.

Breznik, M., 1998: Storage reservoirs and deep wells in karst regions. - A.A. Balkema, p. 268, Rotterdam/ Brookfield.

Breznik, M., 2005: Vodni viri Slovenske Istre (Water sources of Slovene Istria, in Slovene). -Unpublished report to the Ministry for Environment and Physical Planning, 1-35, Ljubljana.

Doctor, D. \& S. Lojen \& M. Horvat, 2000: A stable isotope investigations of the classical Karst aquifer: Evaluating karst groundwater components for water quality preservation. - Acta carsologica 29/1, 7992, Ljubljana.

Economopoulos, P., 1983 and 1989: Situation of estavelles and coastal spring in Bali bay, scale 1:25000. - Unpublished map, photo, written communications to Breznik.
Gjurašin, K., 1943: Prilog hidrografiji primorskog krša. - Tehnički vjesnik 1-2, 1-17, Zagreb.

Glanz, T., 1965: Das Phaenomen der Meermuhlen von Argostolion. - Steirische Beitrage zur Hydrogeologie 1965, 113-127, Graz.

Gospodarič, R. \& C. Leibungut, 1986: Evaluation and Interpretation of the Tracing data. In: Morphia, A. \& a. Zojer (ds.): Hydrogeology of the Eastern Peleponissos, Greece. - 5th Int. Symp. on Underground Water Tracing, 100-110, New York.

Herzberg, A., 1901: Die Wasserversorgung einiger Nordseebader. - Zeitung für Gasbeleuchtung und Wasserversorgung 44, 815-819, Muenchen.

Kajfež-Bogataj, L., 2006: Glede spreminjanja podnebja Slovenija ni izjema. - Proteus 2/69, 54-61, Ljubljana.

Kajfež-Bogataj, L., 2007: Poročili, ki spreminjata poglede na podnebne spremembe. Pentagon and Stern reports. - Proteus 7/69, 294-302, Ljubljana.

Kajfež-Bogataj, L., 2008: Dezertifikacija: mnogo več kot le ekološki problem. - Proteus 9, 10/70, 390-400, Ljubljana.

Krivic, P., 1982: Variations naturelles de niveau piezometrique d' un aquiffére karstique. - Geologija 25/1, 129-150, Ljubljana.

Kuščer, I., 1950: Kraški izviri ob morski obali (Karst Sources at the Sea Coast, in Slovene). - Dissertationes Academia Scientarium et Artium Slovenica Classis III 1, 97-147, Ljubljana.

Kuščer, I. \& D. Kuščer, 1962: Observations of Brackish Karst Sources and Swallowholes in the Yougoslav Coast. - Mem. de l' Ass. Intern. Des Hydrogeologues. V. Reunion d'Athens.

Lambrakis, N., 2005: Kiveri coastal springs, Greece. EUR 21366 En, COST Action 621, p. 262, Brussels.

Maurin, V. \& J. Zoetl, 1965: Salt Water Encroachment in the Low Altitude Karst Water Horizons of the Islands of Kefalonia. - Actes Coll. AISH-UNESCO 2, 423-438, Dubrovnik.

Monopolis, D. \& N. Lambrakis \& B. Perleros, 2005: The brackish karstic spring of Almiros of Heraklion. EUR 21366 En, COST Action 621, 321-328, Brussels.

Mueller, I. \& Schotterer, U., 1986: Electromagnetic VLF Resistivity Prospection in the Region of Tripolis and the Coastal area of Argos - Astros. - 5th Symp. of Underground Water Tracing, 425-440, Athens.

Nonveiller, E., 1989: Grouting Theory and Practice. Elsevier, (Developments in geotechnical engineering; 57), p. 250, Amsterdam.

Panagopoulos, A., 2005: Almiros spring, Heraklion, Greece. - EUR 21366 En, COST Action 621, p. 258, Brussels. 
Pavlin, B., 1990: Yugoslav littoral belt karst springs used for water supply. - 6th Int. Cong. Int. Ass. of Eng. Geology, Amsterdam, 1387-1394, Rotterdam: Balkema.

Petrič, M., 2005: Klariči, Brestovica, Slovenia. - EUR 21366 En, COST Action 621, p. 264, Brussels.

Potie, L. \& Ricour, J., 1974. Etudes et captage de résurgences d'eau douce sous-marines. - Ressources en eau, 5-26.

Ré, R. \& M. Breznik, 1968: The problems of the Almyros spring of Iraklion. - Unpublished note No. 2 of UN - FAO, presented to Greek Gov., 1-114, Iraklion.

Roškar, J., 2007: Živimo v najtoplejši dobi v zadnjih 150 tisoč letih. (In Slovene) Delo, Polet, 4, Ljubljana.

Soulios, G., 1987: System karstique aquifére d'Almyros, Iraklion, un case interessant de functionement de systéme littorale. - Bull. Centre d'hydrog., 7, 169191, Neuchatel.

Steinman, F. \& L. Gosar \& P. Banovec, 2004: Preparation of sensitivity maps of the Slovenian coast - CAMP Slovenia, 1-24 \& maps, Ljubljana.

Steinman, F. \& D. Kozelj \& P. Banovec, 2006: Regional water supply in State development plan (in Slovene). - Slovenian Water Protection Association Proceedings I, 24-32, Portorož.
Steinman, F. et al. 2007: Expert group assessment of the project: Drinking water supply of the Slovenian Istra and Karst hinterland. - Unpublished Report to the Ministry of Environment and Physical Planning (in Slovene), 1-64, Ljubljana.

Ständer, W., 1971: written answer to Breznik.

Šegota, A., 1986: Surface of the Adriatic Sea throughout the last glacial period with part of the present Adriatic Sea emerged as dry land 25.000 years ago. EUR 21366 En, COST Action 621, p. 116, Brussels.

Thérond, R., 1973: Recherche sur l'étancheité des lacs des barrages en pays karstiques. - Eyrolles, p. 444, Paris.

Tiniakos, L. \& J. Tavitian \& A. Livaniou-Tianikou, 2005: The Anavalos-Kiveri coastal spring (Argolis, E. Peloponnesus, Greece): Hydrogeology and droughtwater quality relation. - EUR 21366 En, COST Action 621, 312-320, Brussels.

Vlahović, V., 1983: Kraška akumulacija Slano (Karstic accumulation in Slano). - Crnogorska akademija nauka i umjetnosti (The Montenegrian Academy of Sciences and Arts, in Serbian), 5-246, Podgorica.

\section{POVZETEK}

Meddržavna komisija za klimatske spremembe (IPCC) predvideva $\mathrm{v}$ južni Evropi manj padavin in tudi njihovo manjše ponikovanje zaradi večjega izparevanja ob višjih temperaturah, kar bo močno zmanjšalo pretoke rek in izdatnost izvirov.

Kraške podzemne vode se pretežno pretakajo po žilah, rovih in močno prepustnih tektonskih razpokah. Teorijo zaslanjevanja vodonosnikov s pretokom po rovih so razvili Gjurašin (1943), Kuščer (1950) in Breznik $(1973,1978,1984,1989,1990$ in 1998).

Prestrezanje sladke vode v notranjosti Krasa, izolacija obalnih vodonosnikov $\mathrm{z}$ injekcijsko zaveso ali z umetnim dvigom gladine izvira, ki naj bi preprečili vtok morske vode, ter zmanjšano črpanje sladke vode ob suši so načini za razslanitev vode obalnih kraških vodonosnikov.

Predlagamo, naj bi za izvira Bali in Kiveri izgradili injekcijske zavese, in za Almyros, da bi umetno dvignili gladino izvira s podzemno pregrado.

Naš Kras z obalo ima glavno črpališče Klariči 250 l/ $\mathrm{s}$, ki črpa sladko vodo iz kraškega kanala $26 \mathrm{~m}$ pod mor- sko gladino in je ogroženo zaradi zaslanitve, ter črpališče Rižana s 110 - 200 l/s vode in skupno sedanjo potrebo 500 l/s ob suši. Predlagamo veliko akumulacijo Pinjevec z 20 do 30 milijonov $\mathrm{m}^{3}$ vode dodatno, $250 \mathrm{~m}$ visoko črpane pozimi iz Rižane in poleti pretakane $\mathrm{v}$ cevovod, ki sedaj dovaja vodo iz hrvaških Gradol in v Rižano z zgrajeno čistilno napravo, kar bo rešitev za desetletja, ker poleti vode že sedaj primanjkuje. Dotok vode, akumulirane na višini 310 m.n.m. bo tako možen gravitacijsko, brez elektrike. Spodnji evtrofičen sloj vode, v kaskadah obogaten s kisikom, naj bi namakal ravnici ob Dragonji in pri Sečovljah, kar je že 25 let star predlog kmetijcev. Mešanje vode $\mathrm{v}$ akumulaciji, za preprečevanje evtrofikacije, zato ne bo potrebno.

Sicer predlagana akumulacija Padež zahteva visoko pregrado v ozki dolini, ter stalno črpanje $250 \mathrm{~m}$ visoko na Barko z elektriko, ki ne bo vedno na razpolago, kar dokazujejo »električni mrki« v razvitih državah. Vodo $\mathrm{v}$ akumulaciji bo treba mešati, da bi preprečili evtrofikacijo. 